\title{
Reproductive and morphological performance in the stallion in humbang hasundutan distric
}

\author{
Lestari Evangelina Simamora, Hamdan, I Sembiring, M Tafsin and Hasnudi \\ Departement Animal Husbandry Faculty Agriculture Universitas of sumatera utara \\ lestarievengelinasimamora@ gmail.com
}

\begin{abstract}
This study aims to determine the reproduction and morphological performance of the stallion in Humbang Hasundutan Regency. This research was conducted in Humbang Hasundutan Regency and cement test at Livestock Breeding and Animal Feed Siborong-borong on July - August 2017. This research was conducted on 15 adult stallion. Then by using Ms Excel data application in input to know total, mean, standard deviation, coefficient of diversity. The results showed that in the macroscopic test the cement volume has a coefficient of $7.74 \%$ diversity. The color obtained is white gray. $75 \%$ viscous viscosity, $26 \%$ dilute. $\mathrm{pH}$ diversity coefficient $6.79 \%$. In the microscopic test that motility has a coefficient of $9.91 \%$ diversity. The concentration has a diversity coefficient of $7.74 \%$. 90\% Abnormalities Normal, 10\% abnormal. Measurements of morphology include coefficient of diversity of head length 2,71 , head width $4.54 \%$, length of neck $5.04 \%$ height of shoulder $1,89 \%$ of circumference of chest $3.40 \%$, depth of breasts $6.84 \%$, length of body $3,765 \%$, height of hip $2.16 \%$, Hole width $3,14 \%$, Scrotum diameter $9.45 \%$. The coefficient of data obtained shows the number below 10 which means the sample data is taken to show a uniform value. The uniforms obtained indicate good quality score values for breeding.
\end{abstract}

\section{Introduction}

Some districts are well known for the potential and number of horses so that it becomes one of the objects that is good enough to conduct a study, given that the horse breeders have poor management this is evidenced by the lack of meat production that does not match the number of requests.

Along with the increasing number of population in Indonesia, especially in North Sumatra Province, the growing demand for animal protein fulfillment. These problems require follow-up in the provision of consumption of animal protein. Some animals that have the potential as a source of animal protein are cattle, goats, buffalo and horses.Based on statistical results in North Sumatra book in 2015 figures obtained data that some districts with the largest number of horse cattle in North Sumatra is HumbangHasudutan District, Simalungun Regency, Deli Serdang Regency, Karo Regency. Local horses or Indonesian horse is a type of horse that originated from Indonesia and has lived in the plains of Indonesia for many years. The local horses in HumbangHasundutan district are Batak horse. Farmers like Karo Regency also breed their mares out of the area and bring in stallions from Australia to improve their genetic quality in the future.Some districts in North Sumatra have potential in raising horses such as Karo Regency, Siborong-borong, HumbangHasundutan, Samosir, DeliSerdang. but in the maintenance applied by the people in the area is not maximal and efficient enough, consequently the growth and breeding of horse livestock is not going well. Based on the facts obtained in the field many of the stallion population is not proportional to the number of female populations. It is known that a male stallions marry the entire female population and since this has been the case for many years, if this is done continuously it can cause damage to the genetic diversity of the horse and affect the quality of the stallion's cement.

However, not all districts in North Sumatera can bring horses from outside the region, it is necessary to do some testing both in terms of reproduction and production of horse in one of the regencies in North Sumatra, namely HumbangHasundutan Regency.

The desirable properties of the breeder are beneficial or beneficial properties such as high production and reproductive capacity, number and weight of good birthday puppies, or rapid growth, low mortality, and high food use efficiency (Fahmy and Bernard, 1972). Livestock productivity is enhanced through genetic improvement by selection and marriage and through environmental improvement (Lasley, 1978). To increase the production and reproduction of horse is not enough just feed, environmental and genetic factors but cement and reproductive conditions. To prevent close kinship of the same marriage result in this district and to know the condition of cement horse, cement and morphology checks are done. 


\section{Research Methods}

The research was conducted in two districts, namely Janji Village, Sihite Village, Sirisirisi Village of HumbangHasundutan Regency and in Laboratory of Superior Livestock Breeding Center and Forage of Animal Feed (BPTU-HPT) in Siborong-borongKabupatenTapanuli Utara in June-August 2017.The type of research that will be carried out is direct observation survey with purposive sampling sampling method (intentional sampling with certain criteria) the criteria in this study are local males who have adult sex and adult body to be taken cement and size of morphology.

\section{Results And Discussion}

\subsection{Horse Reproduction Performance}

\subsection{Macroscopic Test of Horse Males}

The macroscopic test includes color, $\mathrm{pH}$, viscosity. This test is done directly in the field. The average yield obtained on the basis of the table is that it has $93.4 \%$ white graycolor, and $6.6 \%$ of aqueous yellow color is the same as Feradis (2010) statement which states that pig and horse cement resembles a starch solution (gray dilute).

The relatively neutral $\mathrm{pH}$ of 6.73 is not significantly different from the statement of Morel (1999) which states that the $\mathrm{pH}$ of horses cement ranges from 6.20 to 7.80 and also with Toelehere's (1986) statement that $\mathrm{pH}$ cement is neutral ranged 6.8-7.0 and condensed condensed percentage percentage of $74.3 \%$ and dilute $26.67 \%$. The standard deviation of $\mathrm{pH}$ is 0.46 and the $6.79 \%$ diversity coefficient. The resulting viscosity percentage value is $74 \%$ and $26 \%$ dilute, the result is quite good because the viscosity value is high. The thicker the cement the concentration of cement is also getting better. This is in accordance with Wibowo's statement (2015). Viscosity or consistency or viscosity is one of the properties of cement that has to do with the density / concentration of sperm in it. The thicker the cement can mean that the higher the sperm concentration.

Table 4. Total, mean, standard deviation, coefficient of diversity from macroscopic test of male stallion cement.

\begin{tabular}{|c|c|c|c|}
\hline No & Cement Macroscopic & & \\
\hline & Color & Viscosity & $\mathrm{pH}$. \\
\hline 1 & white gray & viscous & 7 \\
\hline 2 & white gray & viscous & 7 \\
\hline 3 & Yellowish white & dilute & 6 \\
\hline 4 & white gray & viscous & 7 \\
\hline 5 & white gray & viscous & 7 \\
\hline 6 & white gray & dilute & 6 \\
\hline 7 & white gray & dilute & 6 \\
\hline 8 & white gray & dilute & 6 \\
\hline 9 & white gray & viscous & 7 \\
\hline 10 & white gray & viscous & 7 \\
\hline 11 & white gray & viscous & 7 \\
\hline 12 & white gray & viscous & 7 \\
\hline 13 & white gray & viscous & 7 \\
\hline 14 & white gray & viscous & 7 \\
\hline 15 & white gray & viscous & 7 \\
\hline Total & $\begin{array}{l}93,4 \% \\
\text { yellowish }\end{array}$ & $74 \%$ viscous, $26 \%$ dilute & 101 \\
\hline RR & white gray & viscous & 6,7 \\
\hline SB & - & - & 0,45 \\
\hline KK & - & - & 6,79 \\
\hline
\end{tabular}




\subsection{Microscopic Test of Horse Males}

The total, mean, standard deviation, and coefficient of diversity from microscopic data are presented in Table 3. Microscopic tests include motility, concentration, and abnormality, these tests were performed in the laboratory.

From the following table it can be seen that the average motility is $71 \%$, with standard deviation 0.07 , and the coefficient of diversity is $9.91 \%$. The data show that the cement is in good condition and in a progressive group of movements and indicates that spermatozoa in active condition produce mass movement. This is consistent with the assessment of Toelehere (1993) which states that the assessment of individual movements of spermatozoa has progressive moving values and no wave, 3 : between 50 to $80 \%$ of spermatozoa progressive moves and produce mass movements, 4: agile progressive movements and soon forming waves with 90\% motile sperm, 5: a very progressive movement, very fast waves, showing $100 \%$ motile active (Toelihere, 1993).

From the table it can be seen that the average motility is $71 \%$, with standard deviation 0.07 , and the coefficient of diversity is $9.91 \%$. The data show that the cement is in good condition and in a progressive group of movements and indicates that spermatozoa in active condition produce mass movement. This is in accordance with the assessment of Toelihere (1993) which states that the assessment of individual movements of spermatozoa are in the category of score 3 that is: between $50 \%$ to $80 \%$ of spermatozoa move progressively and produce mass movement. Feradis (2010) also classify this condition good (++), when seen small waves, thin, rare, less clear and moving slowly.

Table 5. Total, mean, standard deviation, average deviation, variety, coefficient of diversity from microscopic test of male stallion cement.

\begin{tabular}{llll}
\hline \multirow{2}{*}{ No } & \multicolumn{3}{c}{ Mikrokopis } \\
\cline { 2 - 4 } & Motilitas & $\begin{array}{l}\text { Konsentrasi } \\
(\mathrm{x} \mathrm{10})\end{array}$ & Abnormalitas \\
\hline 1 & $70 \%$ & 14,40 & Normal \\
2 & $60 \%$ & 15,00 & Abnormal \\
3 & $60 \%$ & 12,60 & Abnormal \\
4 & $75 \%$ & 12,60 & Normal \\
5 & $75 \%$ & 12,00 & Normal \\
6 & $65 \%$ & 13,80 & Normal \\
7 & $79 \%$ & 12,00 & Normal \\
8 & $60 \%$ & 12,60 & Abnormal \\
9 & $80 \%$ & 14,40 & Normal \\
10 & $70 \%$ & 12,96 & Normal \\
11 & $70 \%$ & 12,60 & Normal \\
12 & $75 \%$ & 14,40 & Normal \\
13 & $75 \%$ & 15,00 & Normal \\
14 & $80 \%$ & 13,80 & Normal \\
15 & $70 \%$ & 13,80 & Normal \\
\hline & & & $80 \%$ Normal, \\
Total & $1064 \%$ & 201,96 & $20 \%$ Abnormal \\
\hline RR & $71 \%$ & 13,46 & Normal \\
\hline SB & 0,070 & 1,04 & - \\
\hline KK & 9,91 & 7,74 & - \\
\hline & & & \\
\hline
\end{tabular}

Concentration can be interpreted by the number of spermatozoa contained in each $\mathrm{ml}$ of cement, the number is averaging $134.6 \times 106 / \mathrm{ml}$, with standard deviation 1.04, and the coefficient of $7.74 \%$ diversity. The result is smaller with the statement of Yudi, et al (2008) which states that the concentration of cement is $211.9 \pm 21.2 \mathrm{x}$ $107 / \mathrm{ml}$. 
The abnormality of the data was found to be a normal / solid grouping because the concentration of the cement was in the range of $182.6 \times 106 / \mathrm{ml}$ indicating that the spermatozoa are categorized as solid. This corresponds to Feradis (2010) asserting that Densum (D) or solid, if the distance between two spermatozoa heads is less than the length of one head; concentrations are estimated at approximately 1000 million to 2000 million cells per ml of cement. But in the observation found also some forms of spermatozoa that has a tail that is benkok (bent), not tail, and a dented head.

\section{3. Measurement of Horse Morphology}

The length of the body has a size ranging from $72 \pm 80.1 \mathrm{~cm}$; total 1130.4; average 75.36; standard deviation $2.83 ; 3.76 \%$ diversity coefficient. The hip height has a size ranging from $130 \pm 139.2 \mathrm{~cm}$; total of 2035.4; average 135.69; standard deviation 2.94; coefficient of diversity 2,168\%. The width of the hip has a size ranging from $38 \pm 42 \mathrm{~cm}$; total 602.85; average 40.19; standard deviation 1.26; coefficient of diversity $3,143 \%$. The scrotum circumference has a total of 493.95 , with an average of 32.93 , standard deviation 3.11 , the coefficient of diversity of $2.82 \%$, the size of the scrotum circumference may change according to the conditions of the horse. The size of the scrotum circumference affects the amount of spermatozoa produced.

The results of the above data have a value that is not much different from the statement Grantino F et al (2017) conducted in Nusantara Polo Club West Java Bogor district and West Tompaso District and states that the measurement of the horse's head length with a range of $60.95 \mathrm{~cm} \pm 1.785 \mathrm{~cm}$ with the coefficient of diversity $2.92 \%$. Results Head width has a size not much different from the average of $21.22 \pm 1.99 \mathrm{~cm}$ with the coefficient of diversity $9.41 \%$ and $19.36 \pm 1.32 \mathrm{~cm} ; 6.85 \%$ diversity coefficient in other regions. The measurement of the length of the neck found that the measurement data is greater than the measurement of neck length averaging $49.09 \pm 4.139 \mathrm{~cm}$ with the coefficient of diversity of $8.43 \%$ and in other districts the average length of the horse's neck $56.590 \pm 5.359 \mathrm{~cm}$ with the coefficient of diversity $9.46 \%$.

Table 6. Total, mean, standard deviation, average deviation, variety, coefficient of diversity from horse morphology.

\begin{tabular}{llll}
\hline & Total & Mean \pm SD & KK \\
\cline { 2 - 4 } $\begin{array}{l}\text { Panjang } \\
\text { Kepala }\end{array}$ & 836,6 & $55,77 \pm 1,52$ & $2,72 \%$ \\
Lebar Kepala & 280,2 & $18,68 \pm 0,84$ & $4,53 \%$ \\
$\begin{array}{l}\text { Panjang } \\
\text { Leher } \\
\text { Tinggi }\end{array}$ & 1121,98 & $74,79 \pm 3,76$ & $5,03 \%$ \\
$\begin{array}{l}\text { Pundak } \\
\text { Lingkar }\end{array}$ & 2034,7 & $135,64 \pm 2,575$ & $1,89 \%$ \\
$\begin{array}{l}\text { Dada } \\
\text { Kedalaman }\end{array}$ & 979,28 & $65,28 \pm 4,46$ & $6,83 \%$ \\
$\begin{array}{l}\text { Dada } \\
\text { Panjang }\end{array}$ & 1130,4 & $75,36 \pm 2,83$ & $3,76 \%$ \\
$\begin{array}{l}\text { Badan } \\
\text { Tinggi }\end{array}$ & 2035,4 & $135,69 \pm 2,942$ & $2,16 \%$ \\
$\begin{array}{l}\text { Pinggul } \\
\text { Lebar }\end{array}$ & 602,85 & $40,19 \pm 1,264$ & $3,14 \%$ \\
$\begin{array}{l}\text { Pinggul } \\
\text { Lingkar }\end{array}$ & 493,95 & $32,93 \pm 3,11$ & $2,82 \%$ \\
Scrotum & & & \\
\hline $\mathrm{n}=15$ ekor & & & \\
\hline
\end{tabular}

The results obtained in this study are not much different from the results of Guritno, et al 2017 which has an average shoulder height of $149.54 \pm 5.04 \mathrm{~cm}$ with a coefficient of $3.37 \%$ diversity and the average horse's shoulder level in other districts of $155,36 \pm 5.15 \mathrm{~cm}$ with a coefficient of $3.31 \%$ diversity. And the measurement of chest circumference is also not much different from the average chest circumference of 167,90 $\pm 5,81 \mathrm{~cm}$ with coefficient of diversity $3,41 \%$ and mean of horse chest circumference in other districts that is $177,63 \pm 7,34 \mathrm{~cm}$ with a diversity coefficient of $4.13 \%$. The results of measurement in the chest have a higher value than research Guritno, et al (2017) that has an average chest of $42.45 \pm 4.14 \mathrm{~cm}$ with a coefficient of $9.77 \%$ diversity and average in horse chest in other districts $42,86 \pm 4.85 \mathrm{~cm}$ with a coefficient of diversity of $11.31 \%$. 
The result of body length is smaller than average $146 \pm 3,464 \mathrm{~cm}$ with coefficient of diversity $2,37 \%$ and mean of body length of horse in other district that is $150,363 \pm 4,530 \mathrm{~cm}$ with coefficient of diversity $3,01 \%$. The result of hip height is smaller than the highest average value of $150,636 \pm 4,726 \mathrm{~cm}$ with coefficient of diversity $3,13 \%$ and mean in other regency $152,818 \pm 4,283 \mathrm{~cm}$ with coefficient of $2,80 \%$ diversity. The result of hip width has the same value with the average of $38,954 \pm 1,963 \mathrm{~cm}$ with the coefficient of diversity $5.03 \%$ and the mean horse horse width at $36,681 \pm 3,197 \mathrm{~cm}$ with coefficient of diversity $8,71 \%$. The results of the data are presented by Grantino, F et al (2017) conducted in 2 different districts.

\subsection{Multiple Correlation Analysis}

There are 2 variables which have no correlation, morphology and $\mathrm{pH}$ which have value 0.03 with positive relationship direction, on morphology and motility having value 0.06 with positive relationship direction. The absence of this correlation explains that the morphological size condition of the stallion does not affect the quality value of the motility and $\mathrm{pH}$ of the resulting horse cement.

There is correlation on 1 variable which have weak correlation coefficient with morphology that is at concentration which value 0,31 with direction of positive relation. These results explain that the morphological size has little effect on the concentration and volume values in which the direction of the correlation relationship indicates a positive direction.

\section{Conclusions and suggestion}

The cement quality test performed in microscopic and microscopic examination showed good quality, with $93,4 \%$ white gray, neutral $\mathrm{pH}, 74 \%$ viscosity, with $71 \%$ motility average, $13.46 \times 107$ concentration and 80 sample percentage \% normal. The multiple correlation test between Kulitas cement has a weak relationship with the direction of positive relationship.

The horse morphology of the stallion in HumbangHasundutan district shows an appearance with a coefficient value of diversity below $10 \%$ which means the measurement value of horizontal horse morphology with good condition.

It is suggested to breeders to do periodic marriage with local horse in the regency of HumbangHasundutan because the result of the resulting diversity coefficient shows good quality with uniform value

\section{References}

[1]. Anonim. 2011. Ekonomi Manajerial/Bab9 Keputusan Penentuan Harga Pada Berbagai Bentuk Pasar.Pdf Penentu Harga Pasar\&Hl En\&Pid

[2]. Astari Dewi. 2011. Karakteristik Karkas Kuda Dengan Umur, Jenis Kelamin Dan Pemanfaatan Yang Berbeda Di Kecamatan Binamu, Kabupaten Jeneponto Sulawesi Selatan. Departemen Ilmu Produksi Dan Teknologi. Peternakan Fakultas Peternakan. Institut Pertanian Bogor.

[3].Arif Wibowo, 2012, Nilai Ringkasan Data. Diakses dari http ://arifwibowo@uny.ac.id.pada tanggal 13 juni 2017 pukul 11. 53 WIB

[4]. Bambang Ahmad, I Wayan Arnata, Gusti Ayu Adek, 2011, Rancangan Percobaan. Lintaskata publishing

[5]. Blakely and Bade, 1984. Ilmu Peternakan Gadjah Mada University Press Yogyakarta. Blakely and Bade, 1991. Ilmu Peternakan Edisi ke-4 Gadjah Mada University Press Yogyakarta.

[6]. Blakely, J and Kirgoul Dalton 1984. Merawat Kuda Bunting, Menyiapkan Kelahiran dan Perawatan. UGM Press. Yogyakarta

[7]. Bongianni, 1995. Dalam skripsi berjudul kuda beban sebagai alat transportasi di kecamatan saipar dolok hole Tapanuli Selatan Sumatera Utara. Rahmadani Siregar. 2011. Institusi Pertanian Bogor

[8]. Dewi, Vivian N L. 2011 Asuhan Kebidanan pada Masa Kehamilan. Jakarta. Salemba medika

[9]. Dietl. G. Hoffmann, S \& N. Reinsch, 2005. Mecklenburger Warmblood hourse judge in the mare performance test of warm blood horses. Arch Tiez.

[10]. Edwards, 1994, synthetic inhibitors of elastase. First published : history DOI:10.1002/med.2610140202. Medicial Reserch Reviews

[11], Ensminger, M.E. 1962. Animal Science (Animal Agriculsture Series). 5th Ed. The Interstate Printers \& Publisher Inc

[12]. Feradis, 2010. Bioteknologi Reproduksi pada Ternak, Alfabeta. Bandung. 18,53,74-75,84-85.

[13]. Grantino F. Turangan, Umar Paputungan, Zulkifli Poli, Agustinus Lomboan, 2017. Perbandingan Morfometrik Kuda Di Kecamatan Tompaso Barat Dan Di Nusantara Polo Club Bogor Jawa Barat. Fakultas Peternakan Universitas Samratulangi

[14]. Hafez, E. S. E. 2000. Semen Evaluation in Reproduction In Farm Animals. 7th edition. Lippincott Wiliams and Wilkins. Maryland, USA.

[15].Kabupaten Humbang Hasundutan Dalam Angka, 2016. diakses dari http://humbanghasundutan.bps.go.id pada tanggal 17 april 2017 pukul 21.37 WIB

[16]. Morel.DMCG.1999.Equine Artificial Insemination.Wallingford(UK):cubi publishing 
Mizainul Akbar, 2016. Estimasi Jarak Genetik dan Faktor Peubah Pembeda Kuda di Sumatera Utara Melalui Analisis Kraniometrik. USUpress

[17]. Natasasmita A, Mudikdjo, 1979. Beternak Sapi dan Kerbau. Fakultas Peternakan.Institut Pertanian Bogor.Bogor

Parakkasi, 2006, Standart Normal Kimia Darah Kuda yang Dipelihara Meliputi Nilai Serum Glutamic Piruvic Transaminase (SGPT) Nilai serum Glutamic Oxaloactetic Transminase (SGOT), Nilai Blood Urea Nitrogen (BUN) dan nilai Kreatinin.

[18]. R Toelihere. Mozes. 1977. Fisiologi Reproduksi Hewan Ternak. Angkasa. Bandung

R Toelihere. Mozes. 1979. Fisiologi Reproduksi pada Ternak. Angkasam Cetakan ke tiga Bandung

[19]. R Toelihere.Mozes.1985. Fisiologi Reproduksi pada Ternak. Angkasa Cetakan ke empat Bandung

[20]. R Toelihere, Mozes. 1993. Inseminasi Buatan pada Ternak. Angkasa. Bandung Salisbury, G. W. and N. L. Van Denmark. 1985. Fisiologi dan Inseminasi Buatan pada Sapi (Physiologi and Artificial Insemination of Cattle). Diterjemahkan oleh Djanuar, R. Gajah Mada University Press. Yogyakarta.

[21]. Santosa, U. 2002. Prospek Agribisnis Penggemukan Pedet. Penerbit Penebar Swadaya. Jakarta.

[22]. Sasimowski, E., N. Moore. 1987. Animal Breeding and Production an Outline. Elsevier Science Publishing. USA.

[23]. Suharyadi dan Purwanto, 2009, in statistika untuk ekonomi dan keuangan modern. Jakarta : Salemba Empat

[24]. Sostroamidjojo, S. dan Soeradji. 1990. Peternakan Umum. CV. Yasaguna. Jakarta.

[25]. Tim Embriologi. 2010. Embriologi Bahan Ajar. FKS Unsyiah. Banda Aceh

[26]. Wibowo, Ayyub. 2015. Koleksi Semen dan Pemeriksaan Kualitas Semen. Universitas Lampung. Lampung

[26]. Yudi, Arifianti, B Purwantara,TL Yusuf. 2008. Daya Tahan Semen Segar dan Kualitas Semen Cair dengan Konsentrasi Spermatozoa yang Berbeda dalam Pengdilute Dimitropoulos yang di Modifikasi. Fakultas Kedokteran Hewan IPB 